\title{
Analysis of financial and economic indicators of agricultural enterprises in the region based on open data sources
}

\author{
Sergey Kramarov ${ }^{1, *}$, Lyudmila Sakharova ${ }^{2}$, and Alexander Belyaev ${ }^{3}$ \\ ${ }^{1}$ Surgut State University, 628403, Surgut, Lenin Ave., 1, Surgut, Russia \\ ${ }^{2}$ Rostov State University of Economics (RSUE), 344002, Bolshaya Sadovaya Str., 69, Rostov-on- \\ Don, Russia \\ ${ }^{3}$ Don State Technical University, 344003, Gagarin sq., 1, Rostov-on-Don, Russia
}

\begin{abstract}
The article presents and tested a new technique that allows performing financial and economic analysis of enterprises in a given industry in order to optimize its management, based on open internet data sources, using licensed software, as well as on the basis of classical methods of intellectual data mining (further - IDM), as well as systems of fuzzy logic conclusions. The main advantages of this technique are independence in obtaining data and its universality. With a little improvement, this technique can be used to analyze enterprises in almost any sectors of OKVED. In the future, it is planned to develop a new software package that allows you to perform financial and economic analysis of enterprises in a given sector in automatic mode.
\end{abstract}

\section{Introduction}

The analysis of financial and economic indicators of agricultural production in the region, based on the analysis of industry enterprises, is of great importance both for government authorities that form investment and tax policy, and for potential investors and partners, as well as for the heads of companies. The method of integral estimates [1-8,11], which takes into account the relationship between various indicators of the enterprise, allows to track the possible dynamics of its development, currently is quite widespread. However, it has significant disadvantages associated with a subjective approach to determining expert assessments and does not take into account the specific (sectors) features of the enterprise [10-14]. The main tool for analysis is often financial coefficients, which allow to identify both the dynamics of indicators, and the limits of acceptable values (restrictions) and ratios of indicators. The available criteria, based on which coefficients give a qualitative assessment of the financial condition of the enterprise, are most often based on integral point estimates [3]. Points are awarded automatically, but most indicators have an equal or random weight, and when adding new indicators, entire order of the account has to be

* Corresponding author: maoovo@yandex.ru 
changed. These models are difficult to modify, and a significant problem in them is taking into account the opinions of individual experts, as well as the uncertainty of external conditions. For evaluating financial and economic state of a particular sectors in a particular region, there are techniques that are usually based on the analysis of some aggregate indicators and do not allow for analysis of financial and economic condition of the sector in the region based on performance of individual enterprise is taken from open internet sources. The purpose of this research is to develop and test a new methodology that allows performing financial and economic analysis of enterprises in a particular industry based on open Internet data sources, using classical methods of intellectual data mining (IDM) and a system of fuzzy logical conclusions $[2,5,13]$.

To achieve this purpose, the following tasks have been set and solved.

1) Develop a technique for collecting data from open Internet sources on the financial and economic condition of individual enterprises, suitable for analyzing the state of the OKVED (All-Russian Classifier of Types of Economic Activity) sectors in the region as a whole.

2) Test the developed methodology at OKVED 01 enterprises - Crop and Livestock production, Hunting and Provision of appropriate services in these areas, Rostov region.

3) Perform a statistical analysis of individual financial and economic indicators of the industry, such as the amount of paid taxes (by tax groups and subgroups of the OKVED) and social payments, based on the obtained database.

4) Assess the suitability of currently existing databases on the financial and economic condition of individual enterprises for the development of automated data collection systems based on site parsing and statistical analysis of individual financial and economic indicators of the industry in the region.

5) Develop a new fuzzy-multiple modification of the "Technique for analyzing the financial conditions of the enterprise" to assess the financial and economic condition of the sector in the region from open internet sources using the Audit-IT database $[1,9]$.

\section{Technique for analyzing the financial conditions of the enterprise}

The technique developed by us for collecting data on the financial and economic condition of individual enterprises that are suitable for analyzing the condition of the OKVED sectors in the region from open internet sources includes three steps.

At the first step, a database of enterprises was formed in accordance with the specified classifier code, which allows identifying enterprises in all-Russian data systems by name and TIN.

The site of the Russian and CIS enterprise' database ExportBase was used [4]. The database was formed by selecting OKVED-01 on the example of the region - Rostov region. The formed base included 683 enterprises of the Rostov region OKVED-01.

For each enterprise the database contained the following information: 1) company name; 2) OKVED code; 3) OKVED name; 4) TIN; 5) Main state registration number (further - MSRN); 6) landline and mobile phone numbers; address and postal code; website; 5) Decision maker (full name of director); position of Decision maker; 8) company size; 9) date of registration; 10) city; time zone.

At the second step, open data on enterprises was collected using specially developed software from the sites: "For honest business" [6] and "Your financial analyst" [1]. The enterprise's TIN was used to find the enterprise's page. 
At the third step, the received reports are analyzed for their suitability for analysis. It was found that from the list of 683 agricultural enterprises in the Rostov region: 8 enterprises were liquidated; 41 are in the process of liquidation. Among the remaining enterprises, 379 enterprises completely lack data. The remaining 255 enterprises are considered suitable (or partially suitable) for the analysis.

Based on the made database, a statistical analysis of financial statements of enterprises was performed and their clustering was carried out by subgroups of OKVED: 01.1 "The Cultivation of one-year crops"; 01.2 "The Cultivation of multiyear crops", 01.3 "The Cultivation of seedlings"; 01.4. "Livestock"; 01.5 "Mixed agriculture"; 01.6 "Provision of services in the field of agriculture".

Table 1 shows the calculated total tax values, by type, for the OKVED 01.1 "subgroup "growing one-year crops". The graphical analysis of the structure of the amount of paid taxes is shown in Fig. 1. The data is presented in rubles.

Table 1. Analysis of taxes paid by group 01.1 - "The Cultivation of one-year crops"

\begin{tabular}{|l|l|l|}
\hline Data on payments of simplified taxation system (STS) are available for 53 enterprises \\
\hline Total STS & 12584659,82 & Of these, $19=0$ \\
\hline Average STS & 190355,3164 & \\
\hline Data on payments of Income Tax are available for 72 enterprises \\
\hline Total Income Tax & 31459745,93 & Of these, $43=0$ \\
\hline Average Income Tax & 332007,3003 & \\
\hline Data on payments of Land Tax is available for 80 enterprises & Of these, $10=0$ \\
\hline Total Land Tax & 36632863,78 & \\
\hline Average Land Tax & 402558,94 & Of these, $29=0$ \\
\hline Data on payments of Property Tax is available for 69 enterprises \\
\hline Total Property Tax & 59019089,94 \\
\hline Average Property tax & 739432,4154 & \\
\hline Data on payments of VAT is available for 87 enterprises \\
\hline Total VAT & 486009168,3 & Of these, $49=0$ \\
\hline Average VAT & 4277430,681 & \\
\hline Data on payment of Transport Tax is available for 84 enterprises \\
\hline Total Transport Tax & 9864091,02 & Of these, $19=0$ \\
\hline Average Transport Tax & 101691,66 & \\
\hline
\end{tabular}




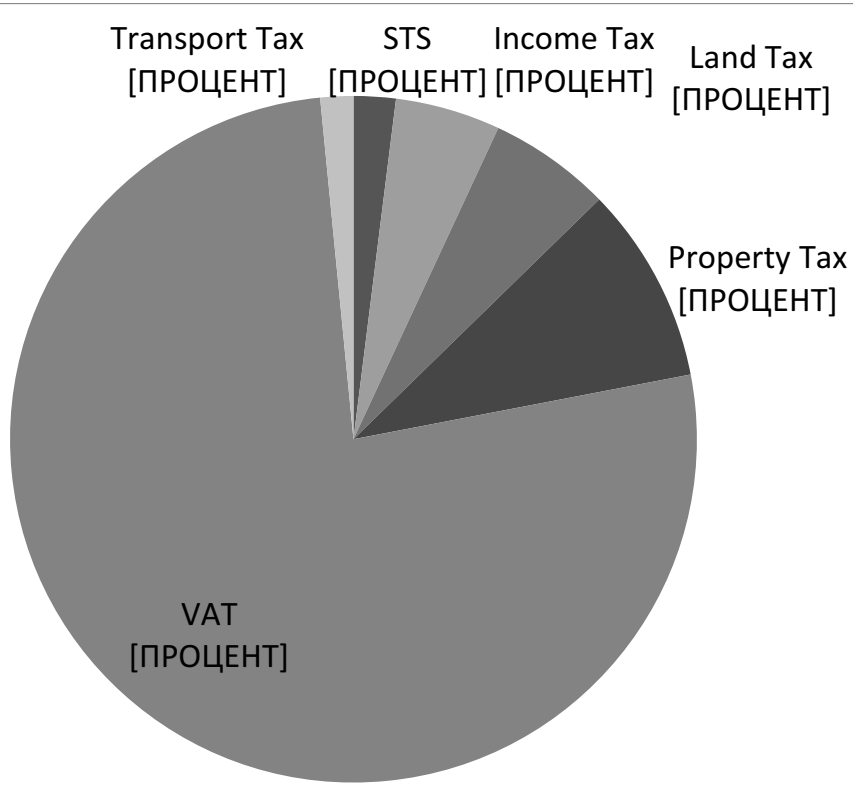

Fig. 1. Analysis of the share contribution of six types of tax in the total amount of taxes paid by enterprises of the group 01.1 - Cultivation of one-year crops

Similar results were obtained for all other subgroups. The results are shown in tables 2 and 3 , as well as in figures 2 and 3. From all the presented diagrams, it is clear that the largest contribution to all payments is made by OKVED 01.1 enterprises, which indicates that at the moment in the Rostov region "Growing one-year crops" is the most developed and priority direction.

Table 2. Analysis of the amount of paid taxes

\begin{tabular}{|l|l|l|l|l|l|l|l|}
\hline $\begin{array}{l}\text { Sub } \\
\text { Group }\end{array}$ & STS & $\begin{array}{l}\text { Income } \\
\text { Tax }\end{array}$ & Land Tax & $\begin{array}{l}\text { Property } \\
\text { Tax }\end{array}$ & VAT & $\begin{array}{l}\text { Transport } \\
\text { Tax }\end{array}$ & Total \\
\hline 01.1 & $\begin{array}{l}12584659, \\
8\end{array}$ & $\begin{array}{l}31459745, \\
9\end{array}$ & $\begin{array}{l}36632863, \\
8\end{array}$ & 59019089,9 & 486009168,3 & $\begin{array}{l}9864091,0 \\
2\end{array}$ & $\begin{array}{l}6355696 \\
18,8\end{array}$ \\
\hline 01.2 & 552821,00 & 113026 & 196342,33 & 1415362,00 & 1669181,86 & 125350,50 & $\begin{array}{l}4072083, \\
69\end{array}$ \\
\hline 01.4 & 18185,00 & $\begin{array}{l}29852364, \\
1\end{array}$ & 2144221,0 & 29516900,6 & 189569342,4 & 829840,00 & $\begin{array}{l}2519308 \\
53,1\end{array}$ \\
\hline 01.5 & 608731,00 & 620555 & 425375,08 & 6381857 & 5071084,51 & 347615,73 & $\begin{array}{l}1345521 \\
8,32\end{array}$ \\
\hline 01.6 & 8331992,3 & $\begin{array}{l}5972524,0 \\
3\end{array}$ & 542089,91 & 1008890,00 & 22669603,99 & 531215,11 & $\begin{array}{l}3905631 \\
5,37\end{array}$ \\
\hline Итог & $\begin{array}{l}22096389, \\
2\end{array}$ & $\begin{array}{l}68018215, \\
0\end{array}$ & $\begin{array}{l}39940892, \\
1\end{array}$ & 97342099,6 & 704988381,1 & $\begin{array}{l}11698112, \\
4\end{array}$ & $\begin{array}{l}9440840 \\
89,3\end{array}$ \\
\hline
\end{tabular}




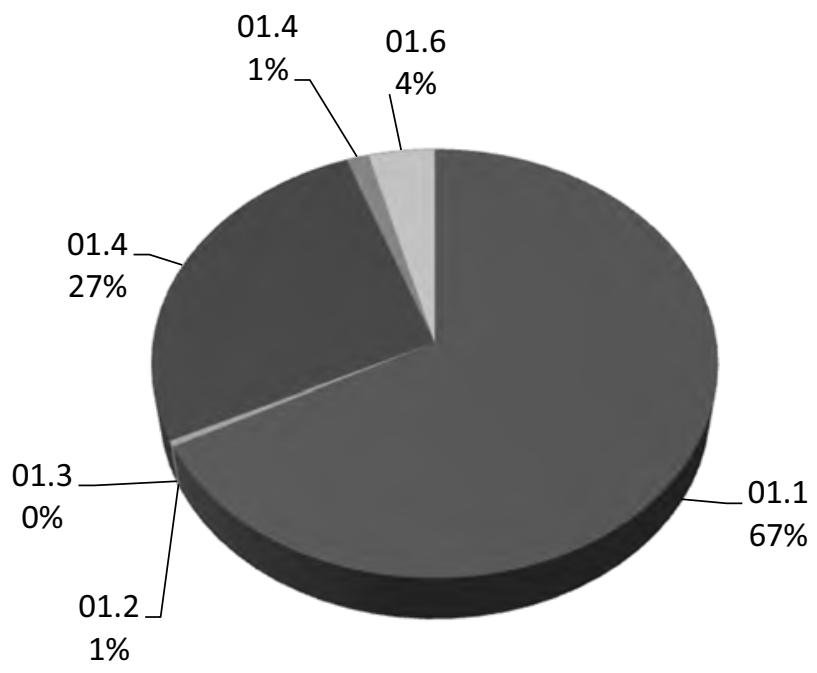

Fig. 2. Analysis of the share contribution of OKVED subgroups in the total amount of taxes

Table 3. Analysis of the amount of social benefits

\begin{tabular}{|l|l|l|l|l|}
\hline Sub group & $\begin{array}{l}\text { Social } \\
\text { insurance }\end{array}$ & $\begin{array}{l}\text { Pension } \\
\text { insurance }\end{array}$ & $\begin{array}{l}\text { Health } \\
\text { insurance }\end{array}$ & Total \\
\hline 01.1 & 44986810 & 349243945 & 81931115 & 476161870 \\
\hline 01.2 & 641545 & 4891307 & 1136388 & 6669240 \\
\hline 01.4 & 9125402 & 69688873 & 16253899 & 95068174 \\
\hline 01.5 & 179357 & 1369367 & 317818 & 1866542 \\
\hline 01.6 & 1668135 & 12827835 & 2975302 & 17471272 \\
\hline Total & 56601249 & 438021327 & 102614522 & 1194474196 \\
\hline
\end{tabular}

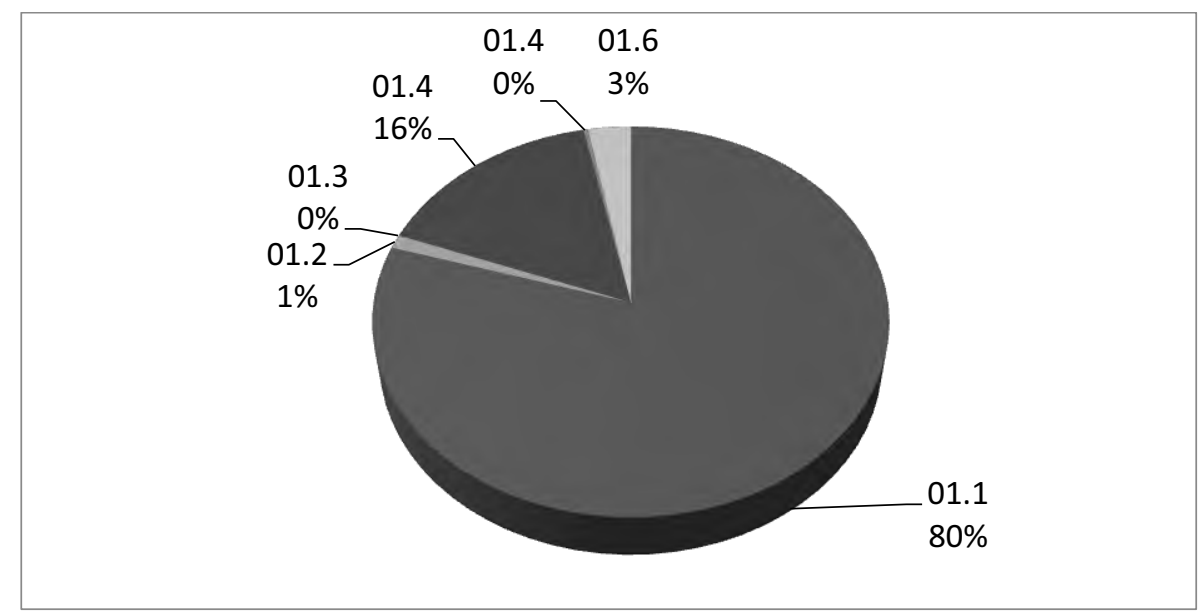

Fig. 3. Analysis of the share contribution of OKVED subgroupsin the total amount of social payments 
This analysis allows us to analyze the distribution of the tax burden by type of tax, as well as to evaluate the distribution of social benefits by type of insurance.

To assess the financial and economic conditions of the sectors, we used a modified fuzzy multiple method based on Audit-IT [1], which includes an analysis of the condition of individual enterprises by nine generally accepted coefficients:

1. The coefficient of autonomy

$\infty<$ critical $\leq 0<$ unsat. $<0.55 \leq$ good $<0.65 \leq$ excel. $<0.8 \leq \operatorname{good}<\infty$

2. The coefficient of security of own current assets

$\infty<$ critical $<-0.2 \leq$ unsat. $<0.1 \leq$ good $<0.15 \leq$ excel. $<\infty$

3. The coefficient of investment coverage

$\infty<$ critical $<0.5 \leq$ unsat. $<0.85 \leq$ good $<0.9 \leq$ excel. $<\infty$

4. The coefficient of the current (general) liquidity

$\infty<$ critical $<1 \leq$ unsat. $<2 \leq \operatorname{good}<2.1 \leq$ excel. $<\infty$

5. The coefficient of quick (intermediate) liquidity

$\infty<$ critical $<0.5 \leq$ unsat. $<0.8 \leq$ good $<1 \leq$ excel. $<\infty$

6. The coefficient of absolute liquidity

$\infty<$ critical $<0.05 \leq$ unsat. $<0.15 \leq$ good $<0.2 \leq$ excel. $<\infty$

7. Profitability of sales

$\infty<$ critical $<0 \leq$ unsat. $<0.09 \leq$ good $<0.2 \leq$ excel. $<\infty$

8. Standard of clear profit

$\infty<$ critical $<0 \leq$ unsat. $<0.06 \leq$ good $<0.12 \leq$ excel. $<\infty$

9. Return on assets (ROA)

$\infty<$ critical $<0 \leq$ unsat. $<0.06 \leq$ good $<0.1 \leq$ excel. $<\infty$

The above data are based on fuzzy multi-level [0,1] classifiers, where aggregation of weights of four terms ("critical", "unsat.", "good", "excel.") within each of the subgroups, OKVED were obtained with subsequent convolution of the final vector of weights to their centers of gravity [12].

As a result, the following values of the linguistic variable "assessment of the financial and economic condition of the subgroup":

01.01. "The cultivation of one-year crops", $\mathrm{G}=0,3001$ (term "unsat.")

01.11. "The cultivation of cereals, legumes and oilseeds", G=0,5431 (term «good»);

01.11.1. "The cultivation of crops", $\mathrm{G}=0,596$ (term «good»);

01.13. "The cultivation of vegetables, melons, root and tuber crops, mushrooms and truffles", G=0,599 (term «good»);

01.13.1. "The cultivation of vegetables", $\mathrm{G}=0,491$ (term «unsat.», near to «good»);

01.13.6. "The cultivation of mushrooms and truffles", $\mathrm{G}=0,324$ (term «unsat.»);

01.2. "The cultivation of multiyear corps", $\mathrm{G}=0,454$ (term «unsat.»);

01.4. "Livestock"; $\mathrm{G}=0,410$ (term «unsat.»);

01.5. "Mixed agriculture", $\mathrm{G}=0,558$ (term «good»);

01.6. "Provision of services in the field of agriculture", $G=0,599$ (term «good»).

Thus, the developed technique allows to study the financial and economic indicators of the industry based on open sources of internet data.

In general, the experiment showed the possibility of a comprehensive study of the financial and economic condition of agricultural enterprises in the region based on open internet data using specialized software. This data analysis requires additional work to "clean" the data. The development of this direction can be significantly enhanced in the process of improving the corresponding automatic systems and services. The developed methodology can be automated in the future by creating appropriate programs and web services, which will allow for a more detailed and accurate analysis of the situation in a 
given sector: identify the main trends, determine the structure, calculate aggregate indicators of the sector, summarizing enterprises by the number of employees, profits, taxes, etc.

\section{Conclusion}

The new technique has been developed that allows performing financial and economic analysis of enterprises in a given sector, based on open data (internet sources), using appropriate software, as well as on the basis of system methods for managing complex multi-factor systems based on fuzzy analog controllers [7]. Testing of the technique was carried out at the enterprises of the Rostov region OKVED-01 (Crop and Livestock production, Hunting and Provision of appropriate services in these areas) and showed its sufficient effectiveness. The main advantages of this technique are independence in obtaining data and its universality. With a little improvement, this technique can be used to analyze enterprises in almost any sectors of OKVED. In the future, it is planned to develop a new software package that allows you to perform financial and economic analysis of enterprises in a given sector in automatic mode.

\section{References}

1. Audit-IT/ru. Financial analysis based on reporting data. https://www.auditit.ru/finanaliz/features/ (Last accessed 20.07.2020)

2. L. O. Cezarino, Geospatial open data sources in Brazil. Espacios, 38(11), 26-33 (2017) https://www.researchgate.net/publication/316958512_Geospatial_open_data_sources_i n_Brazil. (Last accessed 10.06.2020)

3. F. L. Khripliviy, A. F. Khripliviy, Comparative analysis of methods for assessing the financial condition of the enterprise Polythematic network electronic scientific journal of Kuban State Agrarian University, 81, 1-22 (2012)

4. Database of Russian and CIS enterprise. https://export-base.ru/ (Last accessed 06.06.2020)

5. M. Dimitrijević, S. Vrzina, M. Lekovic, Agricultural Enterprises and Economic Growth: A Regional Analysis in the Republic of Serbia. Ekonomika poljoprivrede, 67(2), 585-600 (2020) DOI:10.5937/ekoPolj2002585D. (Last accessed 11.05.2020)

6. FORTHEHONESTBUSINESS. Information portal. https://zachestnyibiznes.ru (Last accessed 16.07.2020)

7. M. Hany, B. A. Youssef, S. M. Darwish, O. Hosam, Intelligent Watermarking System Based on Soft Computing. Proceedings of the International Conference on Advanced Intelligent Systems and Informatics 2019 (2020) DOI:10.1007/978-3-030-31129-2_3. (Last accessed 20.07.2020)

8. M. S. Kuvshinov, Innovative tools for forecasting and evaluating the financial condition of an enterprise, Bulletin of the South Ural State University, Series: Economics and management, (30), 56-66 (2012)

9. H.-S. Kang, Agricultural Total Factor Productivity and Agricultural Exports: Based on the Major Agricultural Exporting Countries (2017) DOI: 10.16980/jitc.13.5.201710.239. (Last accessed 10.06.2020)

10. S. Melnyk, N. Shuprudko, I. Kolosovska, I. Berest, M. Pasichnyk, Anti-crisis personnel management in the process of ensuring the economic security of the 
enterprise. Business: Theory and Practice ISSN 1648-0627, eISSN 1822-42022020, 21(1), 272-281 DOI: https://doi.org/10.3846/btp.2020.11438 (Last accessed 20.07.2020)

11. D. Saini, J. H. Yousif, Environmental Scrutinizing System based on Soft Computing Technique. International Journal of Computer Applications, 62(13), 45-50 (2013) DOI: 10.5120/10143-4952. (Last accessed 20.07.2020)

12. L. S. Sakharova, M. B. Stryukov, T. V. Alekseychik, T. V. Bogacheva, Yu. V. Kulikova, Assessment of the sustainability of agricultural production in the region based on five-level fuzzy $[0,1]$ classifiers. International research journal, 6-2(72), 4551 (2018)

13. T. Yalamov, V. Albena, M. Arabadzhieva, Economic performance of agricultural enterprises in Bulgaria. Bulgarian Journal of Agricultural Science, 27(5) (2020) URL: https://www.researchgate.net/publication/342515371_Economic_performance_of_agri cultural_enterprises_in_Bulgaria. (Last accessed 16.07.2020)

14. N. Ihnatenko, L. Marmul, Financial and investment sources and resources of ensuring competitiveness of agricultural enterprises. University Economic Bulletin (2020) DOI: $10.31470 / 2306-546 \mathrm{X}-2020-44-13-18$ 